\title{
THE INCIDENCE OF RHEUMATISM
}

BY

\author{
BRYCE R. NISBET \\ Medical Officer of Health, Burgh of Kilmarnock
}

In the Report of the Medical Advisory Committee (Scotland) on the Chronic Rheumatic Diseases, the fact is stressed that "there are no means at present of assessing the amount of rheumatism among the non-insured population or in nonincapacitated insured persons".

In an attempt to provide figures relating to a whole population (though a small one) an inquiry was devised to ascertain the amount of rheumatism medically treated in the Burgh of Kilmarnock and the immediate surrounding district-population 40,000 (estimated)—during the month of November, 1945.

\section{Method}

Every general practitioner in the Burgh was approached and the scheme outlined to them. Each agreed to furnish information daily, on a specially designed card, of all his items of service, and of all services in respect of rheumatic conditions. Spaces on the card were reserved for noting rheumatic cases seen for the first time during the month, and also for noting the type of rheumatism. The card was also divided for sex and age, there being three age groups for each sex: under 15 years, i.e. children; 15 to 65 years, i.e. persons of working age; and over 65 years, i.e. mainly retired persons. The cards were taken to the doctors' surgeries daily, and when the cards for the day of call were left the completed cards for the previous day were collected and brought to the Public Health Department. The information from the cards was abstracted daily, and if there was any doubt about the meaning of an entry personal contact was made with the practitioner so as to be sure that no wrong interpretation took place.

The classification of rheumatism adopted was that suggested in the Report of the Medical Advisory Committee, as follows:
Acute group

(a) Rheumatic fever

(b) Subacute rheumatism
Articular group

(a) Rheumatoid type

(b) Osteo-arthritic (b) Neuritic type type
The findings are set forth in Tables 1 and 2 .

TABLE 1

SHOWING ALL ITEMS OF SERVICE AND THOSE IN RESPECT OF RHEUMATIC DISEASES-NOVEMBER, 1945

\begin{tabular}{l|r|r|r|r|r|r|r}
\hline & \multicolumn{2}{|c|}{ Males } & \multicolumn{2}{|c|}{ Females } & Total \\
\cline { 2 - 7 } & $\begin{array}{c}\text { Under } \\
15\end{array}$ & $\begin{array}{c}15-65 \\
\text { yrs. }\end{array}$ & $\begin{array}{c}\text { Over } \\
65\end{array}$ & $\begin{array}{c}\text { Under } \\
15\end{array}$ & $\begin{array}{c}15-65 \\
\text { yrs. }\end{array}$ & $\begin{array}{c}\text { Over } \\
65\end{array}$ & Total \\
\hline $\begin{array}{l}\text { All items of } \\
\text { service, i.e. } \\
\text { visits and } \\
\text { consultations }\end{array}$ & 1,296 & 5,754 & 508 & 1,371 & 7,902 & 809 & 17,640 \\
\hline $\begin{array}{l}\text { Items, i.e., } \\
\text { visits and con- } \\
\text { sultations, in } \\
\text { respect of } \\
\text { rheumatic } \\
\text { conditions }\end{array}$ & 21 & 528 & 21 & 25 & 591 & 42 & 1,228 \\
\hline
\end{tabular}

TABLE 2

SHOWING CASES SEEN FOR THE FIRST TIME DURING NOVEMBER, 1945, REFERRED TO AS NEW CASES, ARRANGED ACCORDING TO THE CLASSIFICATION SUGGESTED BY THE MEDICAL ADVISORY COMMITTEE

\begin{tabular}{|c|c|c|c|c|c|c|c|}
\hline \multirow{3}{*}{$\begin{array}{l}\text { Population at } \\
\text { risk }\end{array}$} & \multicolumn{3}{|c|}{ Males } & \multicolumn{3}{|c|}{ Females } & \multirow{2}{*}{ Total } \\
\hline & $\underset{15}{\text { Under }}$ & $\begin{array}{c}15-65 \\
\text { yrs. }\end{array}$ & $\begin{array}{c}\text { Over } \\
65\end{array}$ & $\begin{array}{c}\text { Under } \\
15\end{array}$ & $\begin{array}{c}15-65 \\
\text { yrs. }\end{array}$ & $\begin{array}{c}\text { Over } \\
65\end{array}$ & \\
\hline & 5,276 & 12,000 & 1,790 & 5,295 & 13,524 & 2,115 & 40,000 \\
\hline $\begin{array}{l}\text { Acute } \\
\text { rheumatism } \\
\text { Subacute } \\
\text { rheumatism }\end{array}$ & - & $\begin{array}{r}3 \\
14\end{array}$ & - & $\begin{array}{l}1 \\
2\end{array}$ & $\begin{array}{r}3 \\
17\end{array}$ & - & $\begin{array}{r}7 \\
37\end{array}$ \\
\hline $\begin{array}{l}\text { Articular: } \\
\text { Rheumatoid } \\
\text { arthritis } \\
\text { Osteo- } \\
\text { arthritis }\end{array}$ & - & 23 & 7 & - & $\begin{array}{l}29 \\
13\end{array}$ & 6 & $\begin{array}{l}59 \\
32\end{array}$ \\
\hline $\begin{array}{l}\text { Non-articular: } \\
\text { Muscular } \\
\text { rheumatism } \\
\text { Neuritic } \\
\text { rheumatism }\end{array}$ & - & $\begin{array}{r}154 \\
53\end{array}$ & 6 & 3 & $\begin{array}{r}131 \\
56\end{array}$ & $\begin{array}{r}10 \\
7\end{array}$ & $\begin{array}{l}309 \\
121\end{array}$ \\
\hline $\begin{array}{l}\text { Total new } \\
\text { cases.. }\end{array}$ & 7 & 254 & 19 & 7 & 249 & 29 & 565 \\
\hline
\end{tabular}

An effort was made to repeat the investigation during the month of March, 1946, but unfortunately on this occasion the doctors in one partnership were unable to take part in the inquiry. From the information gained in November the new population at risk was, therefore, estimated at approximately 30,000 . The figures for the second part of the investigation are shown in Tables 3 and 4.

TABLE 3

SHOWING ALL ITEMS OF MEDICAL SERVICE AND THOSE IN RESPECT OF RHEUMATIC DISEASES-MARCH, 1946

\begin{tabular}{|c|c|c|c|c|c|c|c|}
\hline & \multicolumn{3}{|c|}{ Males } & \multicolumn{3}{|c|}{ Females } & \multirow{2}{*}{ Total } \\
\hline & $\begin{array}{c}\text { Under } \\
15\end{array}$ & $\begin{array}{c}15-65 \\
\text { yrs. }\end{array}$ & $\underset{65}{\text { Over }}$ & $\underset{15}{\text { Under }}$ & $\begin{array}{l}15-65 \\
\text { yrs. }\end{array}$ & $\underset{65}{\text { Over }}$ & \\
\hline $\begin{array}{l}\text { All items of } \\
\text { service, i.e., } \\
\text { visits and } \\
\text { consultations }\end{array}$ & 1,429 & 4,786 & 596 & 1,474 & 5,964 & 953 & 15,202 \\
\hline $\begin{array}{l}\text { Items, i.e., } \\
\text { visits and } \\
\text { consultations, } \\
\text { in respect of } \\
\text { rheumatic } \\
\text { conditions }\end{array}$ & 24 & 367 & 28 & 22 & 356 & 68 & 865 \\
\hline
\end{tabular}

Table 5 shows the parts first affected in articular cases in both months. Table 6 shows the part first affected in non-articular cases, and again relates to both months. 
TABLE 4

SHOWING CASES SEEN FOR THE FIRST TIME DURING MARCH, 1946, ARRANGED ACCORDING TO THE CLASSIFICATION SUGGESTED BY THB MEDICAL ADVISORY COMMITTEE

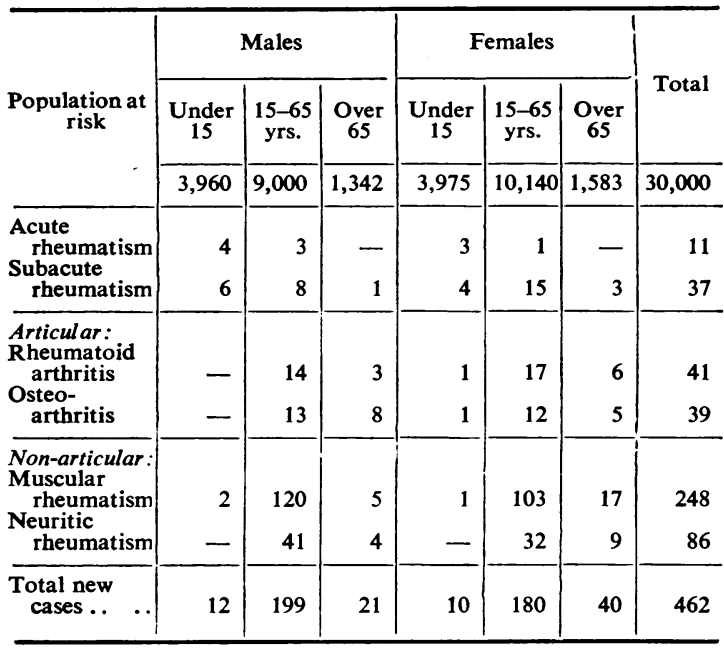

TABLE 5

PARTS FIRST AFFECTED IN ARTICULAR CASES-NOVEMBER, 1945, AND MARCH, 1946

\begin{tabular}{|c|c|c|c|c|c|c|c|c|c|c|c|}
\hline & 忘 & 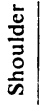 & 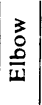 & $\frac{\vec{n}}{3}$ & $\underset{\mathscr{D}}{\stackrel{0}{\Xi}}$ & $\stackrel{c}{I}$ & $\underset{\check{\Sigma}}{\stackrel{\Xi}{\Sigma}}$ & $\frac{\frac{0}{x}}{\frac{L}{L}}$ & 志 & $\frac{n}{\frac{2}{5}}$ & $\begin{array}{l}\bar{J} \\
0 \\
0\end{array}$ \\
\hline Acute rheumatism & - & 1 & 3 & 2 & - & - & 6 & 5 & - & 1 & 18 \\
\hline Subacute rheumatism & - & 6 & 6 & 8 & - & 6 & 17 & 17 & 4 & 10 & 74 \\
\hline Rheumatoid arthritis & 3 & 2 & 2 & 14 & 22 & 3 & 35 & 11 & 5 & 3 & 100 \\
\hline Osteo-arthritis & 11 & 5 & - & 3 & 4 & 18 & 24 & 3 & 2 & 1 & 71 \\
\hline Total $\quad \ldots \quad \ldots \quad \ldots$ & 14 & 14 & 11 & 27 & 26 & 27 & 82 & 36 & 11 & 15 & 263 \\
\hline
\end{tabular}

TABLE 6

PARTS FIRST AFFECTED IN NON-ARTICULAR CASES-NOVEMBER, 1945 , AND MARCH, 1946

Muscular rheumatism

\begin{tabular}{c|c|c|c|c|c|c|c}
\hline Neck & Shoulders & Arm & 'Lumbago' & $\begin{array}{c}\text { Lower } \\
\text { limb }\end{array}$ & $\begin{array}{c}\text { Chest } \\
\text { wall }\end{array}$ & Others & Total \\
\hline 73 & 75 & 5 & 333 & 37 & 7 & 27 & 557 \\
\hline
\end{tabular}

Neuritic rheumatism

\begin{tabular}{c|c|c|c|c|c|c|c}
\hline $\begin{array}{c}\text { Occipi- } \\
\text { tal } \\
\text { neuritis }\end{array}$ & $\begin{array}{c}\text { Brachial } \\
\text { neuritis }\end{array}$ & $\begin{array}{c}\text { Neuritis } \\
\text { of } \\
\text { forearm }\end{array}$ & $\begin{array}{c}\text { Inter- } \\
\text { costal } \\
\text { neur- } \\
\text { itis }\end{array}$ & Sciatica & $\begin{array}{c}\text { Neuritis } \\
\text { of leg }\end{array}$ & Others & Total \\
\hline 8 & 55 & 2 & 25 & 102 & 6 & 9 & 207 \\
\hline
\end{tabular}

\section{Discussion}

Cards were returned by each practitioner for each day he practised during the month of November, 1945; and similarly, with the exception of the partnership which did not participate, cards were returned each day in March, 1946.

The month of November, 1945, was an exceptional one from the meteorological point of view. There was only 0.39 inch of rainfall, and rain fell during $5 \frac{1}{2}$ hours only. It was the driest November on record, i.e., for almost 100 years. March, 1946, on the other hand, showed weather of two distinct types. At the beginning of the month there was a cold spell with temperature below the normal, while from March 17 onwards, the temperature was above normal. There were 2.73 inches of rainfalljust above the average. The following figures indicate the difference in the meteorological conditions:

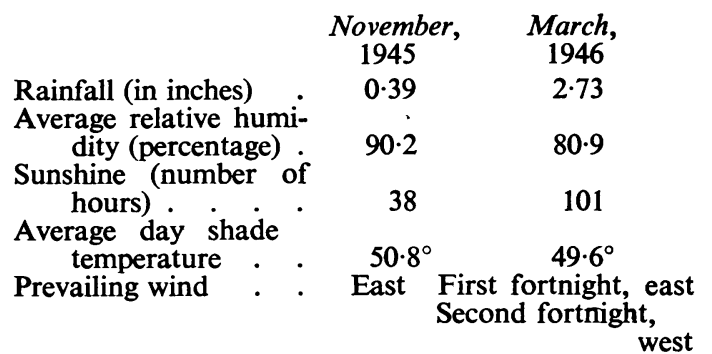

A perusal of the figures in Tables 1 and 3 shows that all items of service, i.e., visits and consultations, were relatively more frequent in the second period -amounting to 44 items per hundred of the population in November, as compared with 51 items per hundred of the population in March. During March there was a considerable amount of measles, whooping-cough, and catarrhal conditions, which may account for some, at any rate, of the increased proportion. Considering the items in respect of the rheumatic conditions, the picture is different. In November there were just over 3 items of service per hundred of the population, and in March there were just under 3 items of service per hundred of the population. The difference in the numbers is very slight although the weather in the two months was quite dissimilar. There was proportionately slightly more acute rheumatism and subacute rheumatism and also osteo-arthritis in March than in November, but the other items - the rheumatoid and the non-articular group-were almost equal in incidence in the two months.

Rheumatic conditions accounted for $6.98 \%$ of all medical attendances during the month of November, 1945 , and for $5.69 \%$ of all medical attendances during the month of March, 1946. These percentages are less than the figure found by Davidson and Duthie (quoted in the Report of the Medical Advisory Committee) viz., 9.4\% of all attendances during an average winter month in 1937 in Aberdeenshire.

Tables 2 and 4 set forth the detailed numbers of rheumatic conditions encountered. It should be clearly understood that in these tables the term " new case" is used in a special sense. The case might in effect be either a new case in the ordinary sense, or a patient suffering from a recurrence of a rheumatic condition and who was attending or being attended for the first time during the month, or a patient already suffering from a rheumatic condition and who was receiving from or paying to his doctor his first visit during the month in question. The figures, then, must not be taken as indicating the true incidence of new cases of rheumatic infection, but rather as indicating the incidence of the different 
types of the rheumatic diseases. Judging from the tables, rheumatism in the young appears to be a very uncommon event in comparison with rheumatism in other age groups. In the working age groups there were significantly greater numbers of rheumatic conditions recorded than in the other groups. (The $\chi^{2}$ test gives $\mathbf{P}<0.01$.) The question of certificates of incapacity for employment may have to be considered in assessing the reasons for the increased incidence at working ages, but this increase occurred in both sexes. There was a less marked emphasis on the female sex, but the difference was still a significant one. The amount of rheumatism in older people is relatively less than at the working age groups. One might reasonably have expected to find an increase in the incidence with increased age. It is possible that by the time a person has reached the age of 65 years he or she may regard some rheumatic conditions as a matter of course, and may, therefore, not seek medical advice so frequently for them. It is almost certain that a much greater proportion of those entitled to free medical service would be seen by doctors than those who had to pay private fees-especially for the less severe types of disease-and in this respect the figures would be unduly loaded with insured persons.

The incidence of acute rheumatism was not great and most of it was met with in the 15-65 years age group.

By "subacute rheumatism" is to be understood a subacute form of rheumatic fever and not an acute form of rheumatoid arthritis. Here the incidence was fairly evenly divided according to age groups, with again a higher incidence at the ages of active work. It should be noted that the incidence of acute and subacute rheumatism in the under 15 age group was higher in March, 1946, than in November, 1945.

Rheumatoid arthritis was only once recorded in a child. A point of interest is the high proportion of cases of rheumatoid arthritis in males in both months. Whereas the proportion of males to females has often been quoted as low as 1 to 3 , in this series of cases it is approximately 2 to 3 . Rheumatoid arthritis was more frequently encountered than osteo-arthritis. This again is at variance with the findings of Davidson and Duthie (Medical Advisory Committee Report), who reported the proportion of rheumatoid cases to osteo-arthritic cases as 5 to 8 . In this series, the proportion was approximately 10 to 7 . Osteo-arthritis was only once recorded in the youngest age group and appeared almost equally often in both sexes.

In the non-articular groups the disease is almost unrecorded in children and surprisingly little recorded in the older age groups. Here the incidence is heavy at the working ages, and the excess of males in the muscular groups is made up almost entirely of cases of lumbago. The neuritic cases showed no marked preference for one sex.

Table 5 sets out the parts first affected in the articular cases. The most outstanding finding was the high incidence of cases showing the first affection in the knee joint. There was no marked difference in the side affected: symptoms began almost equally often in the right, in the left, or in both knees together. It is surprising to find the knee first affected so frequently in all categories, and to find it first affected more than twice as commonly as any other joint. The reason for this high incidence is not clear, but it may be concerned partly at least with the high incidence of males in the rheumatoid group, there being 18 such cases out of the 41 males, and only 17 out of the 59 females.

Table 6 shows that by far the commonest site for muscular rheumatism was the back, and that the only other common sites for this condition were the neck and shoulders. Sciatica took first place in the neuritic group, and in this group the only other condition at all frequently noted was brachial neuritis.

Tables 2 and 4 show that approximately 9\% of the cases recorded were of acute and subacute rheumatism; $17 \%$ were chronic articular cases; $54 \%$ were cases of muscular rheumatism; and $20 \%$ were of neuritic rheumatism.

\section{Summary}

1. The complete figures for medical attendances in general practice are recorded for the Burgh of Kilmarnock and the immediately surrounding district for the month of November, 1945.

2. Similar figures for approximately three-quarters of the population of the Burgh of Kilmarnock are recorded for the month of March, 1946.

3 . The items of service in respect of rheumatic conditions are separately stated.

4. Rheumatic conditions accounted for $6.98 \%$ of all medical attendances during November, 1945, and for $5.69 \%$ of all medical attendances during March, 1946.

5. Details of the rheumatic conditions encountered are recorded.

I wish to thank Professor L. S. P. Davidson, Professor of Medicine, University of Edinburgh, for much helpful advice and criticism; Dr. R. A. Robb of the Mathematics Department, University of Glasgow, for advice on statistics; and Mr. William Dunbar for information regarding the weather in Kilmarnock during the months of November, 1945, and March, 1946. I wish also to record the names of the general practitioners without whose willing help the data would not have been available. They are: Drs. J. G. Allardice (November investigation only), J. Cochran, G. M. Currie, W. D. Frew, R. C. Hamilton, J. McAlister, I. B. K. MacGregor, (March investigation only), P. M. McKillop, W. B. G. Mair, J. W. Peden, A. Robertson, A. C. Scott (November investigation only), and J. Shanks. 